УAK 347.919 .3

\author{
Андронов Ігор Володимирович, \\ Аоктор юриАичних наук, Аоцент, \\ професор кафедри цивільного процесу \\ Національного університету “ОАеська юридична академія"
}

\title{
НЕДОСТАТНІСТЬ ЮРИДИЧНОÏ ВИЗНАЧЕНОСТІ СПРОЩЕНОГО ПОЗОВНОГО ПРОВАДЖЕННЯ
}

Постановка проблеми. ОАнією з цілей останнього оновлення процесуального законодавства України була оптимізація судових процедур, реамізація принципу пропорційності, тобто запровадження більшої Аиференціації процесуальних форм, що Аозволило б значну частину справ розглядати за спрощеною процеАурою, залишивши громіздке загальне позовне проваАження мише А^я тих справ, які за своїми ознаками ії потребують. В результаті судовий захист мав би стати більш швиАким, не втративши при цьому ефективності.

Так, у Аодатках до Рекомендації R (84) 5 Комітету міністрів Аержавам-членам стосовно принципів цивільного судочинства, що направлені на удосконалення судової системи, зокрема у змісті принципу 4 наголошується на тому, що суА, принаймні в першій інстанції, сліА наділити повноваженнями вирішувати, з огляду на характер справи і за винятком випадків, коли зазначене чітко передбачене законом, чи провадження має заійснюватися письмово або усно, або в обидва ці способи. Також забезпечення реалізації положень принципу 8 потребують запровадження конкретних правил чи зведення правил, які прискорюватимуть розв'язання спорів: а) у невіАкладних справах; b) у справах, які стосуються незаперечного права, претензій щодо відшкодування завчасно оцінених збитків та у випадках подання позову на невеликі суми; с) у зв'язку 3 Аорожньо-транспортними пригодами, трудовими спорами, відносинами між орендодавцем і орендатором житла і деякими питаннями сімейного права, зокрема встановленням і перегляАом розміру аліментів.
3 цією метою можна застосовувати один чи кілька з таких заходів: спрощені методи започаткування судового проваАження; віАмова віА суАових засіАань, провеАення кише оАного слухання або, залежно віА обставин, проведення попереднього слухання; зАійснення лише усного проваАження чи проваАження мише на письмі, залежно віА обставин; заборона або обмеження Аеяких заперечень і роз'яснень; гнучкіші правила надання свідчень; відмова віА перерв у слуханнях або проведення засідання мише з короткими перервами; призначення судового експерта exofficio або за клопотанням сторін на початку провадження, якщо це є можливим; активна позиція суду у веАенні справи, виклику свіАків та слуханні свідчень [1].

Варто визнати, що 3 набранням чинності Закону України "Про внесення змін до Господарського процесуального кодексу України, Цивільного процесуального кодексу України, Кодексу аАміністративного судочинства України та інших законодавчих актів" віА 03.10.2017 р. № 2147-VIII, яким було викладено ЦПК України в новій редакції, Ааної мети було частково Аосягнуто, зокрема й внасліАок включення Ао системи цивільного процесу спрощеного позовного проваАження. Значна кількість цивільних справ позовного проваАження стали розгляАатися судами за спрощеною процеАурою, ЗавАяки чому вАалося значно скоротити строки їх розгляАу, Аещо зменшивши навантаження на суди.

Водночас, жодне масштабне оновлення процесуального законодавства не обходиться без недоліків,зокрема у могіці побудування процесуальної моделі судочинства. Вже стало традицією, 
що кожна суттєва зміна цивільного процесуального законодавства призводить Ао ускладнення системи цивімьного процесу, що й сприяє виникненню неузгодженостей та прогалин у правовому регулюванні процедури розгляду та вирішення цивільних справ. Не стала винятком і нова редакція ЦПК України. Недоліки цивільного процесуального законодавства, неузгодженість окремих його норм $€$ порушенням одного з важливих принципів, що $є$ необхідним елементом верховенства права - принципу юридичної визначеності.

Венеціанська комісія наголосила, що принцип юридичної визначеності $€$ істотно важливим Аля питання Аовіри Ао судової системи та верховенства права. Він $€$ істотно важливим також і Аля пліАності бізнесової Аіяльності, з тим щоб генерувати розвиток та економічний поступ. Аби Аосяпи цієї Аовіри, Аержава повинна зробити текст закону (thelaw) легко Аоступним. Вона також зобов'язана дотримуватись законів (thelaws), які запровадила, і застосовувати їх у передбачуваний спосіб та з логічною послідовністю. Передбачуваність означає, що закон має бути, за можливості, проголошений напереА - Ао його застосування, та має бути передбачуваним щодо його насліАків: він має бути сформульований з Аостатньою мірою чіткості, аби особа мала можливість скерувати свою поведінку [2, с. 178].

Юридична визначеність вимагає, щоб юриАичні норми були чіткими і точними та спрямованими на забезпечення того, щоб ситуації та правовіАносини залишались передбачуваними [2, с. 178].

На необхідності забезпечення належної якості законів, чіткості й недвозначності норм законодавства, передбачуваності правових наслідків повеАінки суб'єктів суспільних віАносин як склаАовій принципу юридичної визначеності наполягає у низці своїх рішень і Європейський суд з прав ^юАини (рішення у справах О^ссон проти Швеції [3], Барановський проти Польщі [4], Микола Кучеренко проти України [5] та ін.).

Нечіткість та неузгодженість норм процесуального законодавства призводить до різного їх застосування судами, що, звичайно, не сприяє забезпеченню єАності судової практики та ефективності судового захисту права.

Стан дослідження теми. Науковцями та юристами-практиками неодноразово здійснено ана^із положень нової редакції ЦПК України. Проблематиці спрощеного позовного проваАження та малозначних справ присвячено, зокрема, праці таких вчених як: B.І. Бобрик, С.Б. Булеца,
К.В. Гусаров, В.В. Заборовський, О.Ю. Зуб, І.О. Ізарова, М.Г. Поліщук, О.І. Попов, О.С. Ткачук, О.І. Угриновська, Р.Ю. Ханик-Посполітак та ін.

ОАнак проблема неузгодженості норм цивільного процесуального законодавства України, що регулюють порядок призначення цивільних справ Ао розгляАу в поряАку спрощеного позовного проваАження, залишається невирішеною.

Метою статті є здійснення аналізу підстав віднесення цивільних справ Ао категорії малозначних та призначення їх Ао розгляАу в поряАку спрощеного позовного проваАження, встановлення недоліків правового регулювання даного питання та визначення шляхів їх усунення.

ВикиаА основного матеріалу АосліАження 3 повним обґрунтуванням отриманих наукових результатів. ВіАповідно Ао ст. 274 ЦПК України у порядку спрощеного позовного проваАження розгляАаються справи:

1) малозначні справи;

2) що виникають $з$ трудових відносин;

3) про надання судом Аозволу на тимчасовий виїзА Аитини за межі України тому з батьків, хто проживає окремо віА Аитини, у якого віАсутня заборгованість зі сплати аліментів та якому віАмовлено Аругим із батьків у наАанні нотаріально посвіАченої згоди на такий виїзА.

У поряАку спрощеного позовного проваАження може бути розглянута будь-яка інша справа, віАнесена до юрисдикції суду, за винятком справ, зазначених у частині четвертій цієї статті [6].

Таким чином, основу справ, які розглядаються в порядку спрощеного позовного проваАження, складають малозначні справи.

Відповідно Ао ч. 6 ст. 19 ЦПК України малозначними справами є:

1) справи, у яких ціна позову не перевищує ста розмірів прожиткового мінімуму Аля працездатних осіб;

2) справи незначної складності, визнані судом малозначними, крім справ, які піАлягають розгляАу мише за правилами загального позовного проваАження, та справ, ціна позову в яких перевищує п'ятсот розмірів прожиткового мінімуму Аля працезАатних осіб [6].

СліА зазначити, що закріплений у ЦПК термін "малозначна справа" не має жодного відношення Ао справжньої оцінки того значення, яке справа має Аля суду або сторін. Неупередженість суду, зокрема, означає, що він проявляє однакове ставлення Ао кожної справи, яка знаходиться у його провадженні, а тому жодна справа не може мати Аля нього більшого або меншого значення. 
Що стосується значення справи Аля сторін, особмиво позивача, то її оцінити об'єктивно Аосить важко. Ставлення особи до власної справи залежить віА багатьох суб'єктивних чинників. Можна мише стверАжувати, що якщо особа звернулася Ао суду, то це вже може свідчити, що Аля неї дана справа має Аостатньо важливе значення, принаймні настільки, що вона погодилася оплатити судовий збір та витрати на правову Аопомогу.

Більше того, як сліАує 3 положень п. 2 ч. 3 ст. 389 ЦПК України, як виняток, судове рішення у малозначній справі може бути переглянуте в касаційному порядку, зокрема, якщо справа становить значний суспільний інтерес або має виняткове значення Аля учасника справи, який подає касаційну скаргу, а також якщо суд першої інстанції віАніс справу до категорії малозначних помилково (тобто це Ава окремих самостійних винятки із загального правила про неможливість касаційного оскарження судових рішень у малозначних справах). Аналіз наведених положень процесуального закону Аає піАстави стверджувати, що справа може мати виняткове значення Аля учасника справи і при цьому залишатися малозначною.

Малозначність справи є юридичною характеристикою справи (не пов'язаною з суб'єктивною оцінкою її значення Аля суду та сторін), що має цілком об'єктивні критерії, наявність чи віАсутність яких піААається оцінці судом. За правовою позицією Верховного Суду властивостями, притаманними цивільній справі, за якими визначається, чи є справа малозначною, є ціна пред явленого позову та його преАмет [7]. Такий піАхіА є правильним, хоча й занаАто узагальненим, а тому не дає можливості повною мірою визначити критерії, за якими та чи інша цивільна справа може бути віАнесена до малозначних справ.

Критерії віАнесення справ Ао малозначних, в першу чергу, залежать віА того, чи мають позовні вимоги майновий характер. Майнові позовні вимоги піАлягають грошовій оцінці, а отже мають ціну позову. У випадку, якщо ціна позову не перевищує ста розмірів прожиткового мінімуму Аля працездатних осіб, справа вважається малозначною за прямою вказівкою закону. Як відзначив Верховний Суд, в таких випаАках відсутня необхідність ухвалення окремого судового рішення щодо віАнесення цивільної справи Ао віАповіАної категорії [8]. Також якщо ціна позову перевищує п'ятсот розмірів прожиткового мінімуму Аля працездатних осіб, то справа за прямою вказівкою закону не вважається малозначною.
Не є малозначними й справи, які відповіАно Ао ч. 4 ст. 274 ЦПК України не піАлягають розгляАу в поряАку спрощеного позовного проваАження, Ао яких крім справ, у яких ціна позову перевищує п'ятсот розмірів прожиткового мінімуму Аля працездатних осіб віАносяться також справи, що виникають з сімейних віАносин, крім спорів про стягнення аліментів та поділ майна подружжя; щодо спаАкування; щодо приватизації Аержавного Житлового фонау; щодо визнання необґрунтованими активів та їх витребування відповіАно Ао глави 12 розділу ІІІ ЦПК України [6].

Якщо ж ціна позову знаходиться у межах віА ста Ао п'ятисот розмірів прожиткового мінімуму Аля працезАатних осіб, або позовні вимоги мають немайновий характер, і справа не віднесена Ао категорій справ, що за законом не піляягають розгляАу в поряАку спрощеного позовного проваАження, то питання оцінки такої справи як малозначної віднесене законом на розсуд суду. Основним критерієм Аля суду в такому випаАку є складність справи. Як сліАує з положень п. 2 ч. 6 ст. 19 ЦПК України, суд може визнати малозначною справу незначної складності.

Використання законодавцем оціночної категорії "справа незначної складності" в якості критерію віднесення справи Ао малозначних негативно впливає на юридичну визначеність питання. Як вбачається, наявність кореляції між визнанням справи малозначної та порядком ії розгляАу (в спрощеному позовному проваАженні) Аає підстави стверджувати, що справами незначної складності варто визнавати, зокрема, справи, розгляА яких не потребує проведення піАготовчого засідання. Йдеться про справи, справеАливий, неупереАжений та своєчасний розгляА і вирішення яких можна забезпечити без вчинення процесуальних Аій, передбачених ст. 197 ЦПК України.

Також юридична проблема, яку повинен вирішити суд при розгляді справи, не має бути занаАто склаАною. Як правило, це стосується справ, у яких вже сформована усталена судова практика їх розгляду, зокрема, наявні правові висновки Верховного Суду в аналогічних справах щодо застосування норм закону, що підяягають застосуванню.

Залишається незрозумілою і відповідь на питання, в якій саме процесуальній формі суд повинен визнати справу малозначною у випадках наявності підстав, передбачених п. 2 ч. 6 ст. 19 ЦПК України. Принцип юридичної визначеності вимагає, щоб суА у зрозумілій Аля учасників судового процесу формі усунув будь-яку 
невизначеність у цьому питанні, аАже віА цього залежить можливість реалізації цілої низки важмивих прав учасників судового процесу: права на залучення представника, який не є алвокатом, права на касаційне оскарження судового рішення у цій справі.

Хоча малозначність справи є об'єктивно існуючою юридичною характеристикою справи, юриАичним фактом, який у випадках, передбачених п. 2 ч. 6 ст. 19 ЦПК України, спричиняє правові насліАки, пов'язані з віднесенням справи Ао малозначних справ, є прийняття судом рішення (у формі ухвали) про визнання справи малозначною. Такої правової позиції дотримується й Верховний СуА. При цьому на Аумку Верховного Суду таке рішення може прийняти суд будь-якої, а не мише першої інстанції [9]. Ухвала суду не перетворює справу на малозначну, а лише офіційно піАтверджує таку її юридичну характеристику.

На жаль, процесуальний закон не містить жодної вказівки про те, в якій саме ухвалі суд повинен визнати справу малозначною. Аогічно припустити, що такою ухвалою має бути ухвала про віАкриття проваАження у справі. ОАнак положення ст. 187 ЦПК України не містять обов'язку суду вказувати в ухвалі про відкриття проваАження у справі про визнання справи малозначною з підстав, передбачених п. 2 ч. 6 ст. 19 ЦПК України. У ній закріплено вказівку мише про необхіАність зазначати виА позовного проваАження (загальне або спрощене). Утім призначення справи Ао розгляАу в поряАку спрощеного позовного проваАження не означає автоматичного визнання такої справи малозначною, аАже в порядку спрощеного позовного проваАження розгляАаються й інші крім малозначних цивільні справи. У зв'язку з цим пропонуємо Аоповнити частину Аругу статті 187 ЦПК України пунктом 12 такого змісту: "12) про визнання справи малозначною за наявності підстав, передбачених п. 2 ч. 6 ст. 19 ЦПК України".

Проаналізувавши зміст ст. 274 ЦПК України у співвідношенні з положеннями ч. 6 ст. 19 ЦПК України, можна зробити висновок про неузгодженість цих норм цивільного процесуального законодавства. Про це свідчать наступні аргументи:

1) положення ч. 6 ст. 19 ЦПК України містять Ава окремих обмеження щодо віднесення справи Ао малозначних: якщо справа піАлягає розгляду мише за правилами загального позовного проваАження, та якщо ціна позову перевищує п'ятсот розмірів прожиткового мінімуму Аля працезАатних осіб. Утім сереА справ, що піАлягають роз- гляду мише за правилами загального позовного провадження вже зазначені справи, в яких ціна позову перевищує п'ятсот розмірів прожиткового мінімуму Аля працездатних осіб, а тому додаткове зазначення цього критерію в ч. 6 ст. 19 ЦПК України є зайвим;

2) норма ч. 2 ст. 274 ЦПК України передбачає право суду розглянути в порядку спрощеного позовного проваАження будь-яку справу, крім тих, стосовно яких встановлена пряма законодавча заборона щодо їх розгляду в такому процесуальному порядку (ч. 4 ст. 274 ЦПК України). Тобто справи спрощеного позовного проваАження поАі^яються на Аві групи: а) справи, які піАлягають обов'язковому розгляАу в поряАку спрощеного позовного проваАження (ч. 1 ст. 274 ЦПК України), б) справи, які можуть бути розглянуті в порядку спрощеного позовного провадження (справи позовного провадження, які не відносяться ні до категорій, передбачених ч. 1 ст. 274 ЦПК України, ні до категорій, передбачених ч. 4 ст. 274 ЦПК України). Це фактично Аає суду повноваження розгляАати в поряАКу спрощеного позовного проваАження справи, які не визнані ним малозначними. ОАнак конструкція п. 2 ч. 6 ст. 19 ЦПК України Аозволяє суду визнати малозначною будь-яку справу незначної складності крім тих, що навеАені в ч. 4 ст. 274 ЦПК України. У зв'язку з цим положення ч. 2 ст. 274 ЦПК України втрачають будь-який сенс, оскільки якщо справа $є$ справою незначної складності, то вона може бути визнана судом малозначною і підпадати під Аію ч. 1 ст. 274 ЦПК України, якщо ж справа склаАна, і її не можна визнати малозначною, то відсутні й піАстави Аля її розгляАу в поряАку спрощеного позовного проваАження.

Як видається, положення ч. 2 ст. 274 ЦПК України є такою собі "страховкою" Аля судАі. Тобто навіть якщо суд вищої інстанції дійде висновку, що справа була віднесена Ао категорії малозначних помилково, це все одно не стане підставою Аля направлення ії Аля повторного розгляАу Ао суду першої інстанції вже за правилами загального позовного провадження.

ЗанаАто громізАкою та позбавленою юриАичної визначеності $\epsilon$ й процеАура розгляду судом клопотання позивача про розгляА справи в поряаку спрощеного позовного проваАження у співвідношенні $з$ процедурою надання заперечення віАповіАачем проти розгляду справи в поряАку спрощеного позовного проваАження (ст.ст. 276-277 ЦПК України). У Ааному питанні варто наголосити на наступних аспектах: 
1) у випадках, передбачених ч. 1 ст. 274 цПК України розгляА справи обов'язково відбувається в поряаку спрощеного позовного проваАження, а тому ні клопотання позивача про розглял справи в спрощеному позовному провадженні (його наявність чи віАсутність), ні заперечення віАповіАача проти цього не мають жоАного юридичного значення. Тобто Аумка сторін щодо можливості призначення справи Ао розгляау в поряаку спрощеного позовного провадження може мати Аля суду якесь значення мише у випадках, передбачених ч. 2 ст. 274 ЦПК України;

2) положення ч. 2 ст. 274 ЦПК України не став^ять право СуАУ призначати справу АО розгляАУ в порядку спрощеного позовного проваАження в залежність віА наявності клопотання позивача. У співвіАношенні з нормами ст.ст. 276-277 цПК України це означає, що якщо справа позовного проваАження не віАноситься ні Ао категорій, передбачених ч. 1 ст. 274 ЦПК України, ні Ао категорій, передбачених ч. 4 ст. 274 ЦПК України, суА може призначити ї̈ Ао розгляАУ в поряАКу спрощеного позовного проваАження як за власною ініціативою, так і за клопотанням позивача. Якщо він це робить за клопотанням позивача, то за приписами ст. 277 ЦПК України суА повинен надати віАповіАачу строк Аля подання заяви із запереченнями щоАо розгляАу справи в поряаку спрощеного позовного проваАження. Якщо ж суА приймає таке рішення за власною ініціативою, то жодного узгодження з відповідачем не потрібно. Звичайно таке тлумачення названих положень процесуального закону знецінює прояв ініціативи сторін у вирішенні питання про розгляА справи в спрощеному позовному проваАженні. Воно стало можливим внасліАок неузгодженості норм ч. 2 ст. 274 ЦПК України та ст.ст. 276-277 ЦПК України.

Висновки з АосліАження та перспективи подальших розвіАок у цьому напрямі. В результаті проведеного АосліАження встановлено неузгодженість положень цивільного процесуального законодавства України, на підставі яких суди призначають цивільні справи Ао розгляАу в поряАку спрощеного позовного проваАження.

З метою усунення неузгоАженості норм ЦПК України пропонуємо:

1) викласти пункт Аругий частини шостої статті 19 ЦПК України в наступній редакції: “2) справи незначної складності, визнані судом малозначними, крім справ, які піАлягають розгляду мише за правилами загального позовного провадження";

2) Аоповнити частину Аругу статті 187 ЦПК України пунктом 12 наступного змісту: «12) про визнання справи малозначною за наявності піАстав, передбачених п. 2 ч. 6 ст. 19 ЦПК України";

3) частину Аругу статті 274 ЦПК України викласти в наступній редакції: "2. У порядку спрощеного позовного провадження за клопотанням позивача може бути розглянута будь-яка інша справа позовного проваАження, віАнесена Ао юрисаикції суду, за винятком справ, зазначених у частині четвертій цієї статті».

\section{NITEPATYPA:}

1. Рекомендації R (84) 5 Комітету міністрів державам-членам стосовно принципів цивільного судочинства, що направлені на удосконалення судової системи від 28.02.1984 p. URL: https://zakon.rada.gov.ua/laws/show/994_126.

2. Верховенство права: Доповідь, схвалена Венеційською Комісією на 86-му пленарному засіданні (Венеція, 25-26 березня 2011 року), на основі коментарів, що їх надали: пан Пітер Ван Дайк (член Комісії, Нідерланди) пані Грет Галлер (член Комісії, Швейцарія) пан Джефрі Джоуел (член Комісії, Велика Британія) пан Каарло Туорі (член Комісії, Фінляндія). Переклад на українську мову С. Головатого (за підтримки Американської агенції з міжнародного розвитку/USAID). Право Украӥни. 2011. № 10. С. 168-184.

3. Рішення Європейського суду з прав людини у справі Олссон проти Швеції від 24.03.1988 p. URL: http://hudoc.echr.coe.int/ rus? $\mathrm{i}=001-57548$.

4. Рішення Європейського суду з прав людини у справі Барановський проти Польщі від 28.03.2000 p. URL: http:// hudoc.echr.coe.int/rus?i=001-58525.

5. Рішення Європейського суду з прав людини у справі Микола Кучеренко проти України від 19.02.2009 p. URL: http://hudoc.echr.coe.int/rus?i=001-91395.

6. Ц Цивільний процесуальний кодекс України: Закон України від 18.03.2004 p. № 1618-IV. Відомості Верховної Ради України. 2004. № 40-41, 42. Ст. 492.

7. Постанова Першої судової палати Касаційного цивільного суду Верховного Суду від 24 липня 2019 року у справі № 559/1313/17, провадження № 61-47587св18. URL: http://reyestr.court.gov.ua/Review/83335472.

8. Постанова Першої судової палати Касаційного цивільного суду Верховного Суду від 27 грудня 2018 року у справі № 589/3937/17, провадження № 61-11921св18. URL: http://reyestr.court.gov.ua/Review/78979430.

9. Постанова Другої судової палати Касаційного цивільного суду Верховного Суду від 11 липня 2019 року у справі № 583/783/18, провадження № 61-10656св19. URL: http://reyestr.court.gov.ua/Review/82968166. 


\section{Анаронов Ігор Володимирович}

НЕАОСТАТНІСТЬ ЮРИАИЧНОЇ ВИЗНАЧЕНОСТІ СПРОЩЕНОГО ПОЗОВНОГО ПРОВААЖЕННЯ

У статті викладено наукові результати аналізу положень нової редакції Цивільного процесуального кодексу України та надано оцінку норм, які визначають порядок віднесення цивільних справ до категорії малозначних та призначення цивільних справ Ао розгляду в порядку спрощеного позовного проваАження, з точки зору їх віАповіАності принципу юридичної визначеності. Сформульовано пропозиції щодо вАосконалення правового регу^ювання спрощеного позовного провадження з метою усунення суперечливості норм процесуального закону.

Киючові слова: правосудАя, цивільний процес, малозначні справи, принципи права, позовне проваАження, справа незначної складності, юридична визначеність.

\section{Андронов Игорь Владимирович}

\section{НЕАОСТАТОЧНОСТЬ ЮРИАИЧЕСКОЙ ОПРЕАЕАЕННОСТИ УПРОЩЕННОГО ИСКОВОГО ПРОИЗВОАСТВА}

В статье изложены научные результаты анализа положений новой редакции Гражданского процессуального кодекса Украины и дана оценка норм, устанавливающих порядок отнесения гражданских дел к категории малозначительных и назначения гражАанских Аел к рассмотрению в порядке упрощенного искового производства, с точки зрения их соответствия принципа юридической определенности. Сформулированы преАложения по совершенствованию правового регулирования упрощенного искового производства с целью устранения противоречивости норм процессуального закона.

Киючевые слова: правосудие, гражАанский процесс, малозначительные Аела, принципы права, исковое производство, дело незначительной сложности, юридическая определенность.

\section{Andronov Ihor}

\section{SHORTAGE OF LEGAL CERTAINTY OF SIMPLIFIED CLAIM PROCEEDINGS}

The article presents the scientific results of the analysis of the provisions of the new version of the Civil Procedure Code of Ukraine and provides an assessment of the norms, that determine the procedure for assigning civil cases to the category of insignificant and assigning civil cases to consideration in the order of simplified claim proceedings, in terms of their compliance with the principle of legal certainty.

It is established that the term "insignificant matter» enshrined in the procedural law has nothing to do with the true assessment of the meaning of the case for the court or the parties. The impartiality of the court, in particular, means that it has an equal attitude to every case in its proceedings, and therefore no case can be of greater or lesser importance to it. As regards the value of the case to the parties, especially the claimant, it is not objectively assessed. The insignificance of a case is a legal characteristic of a case that has entirely objective criteria, the presence or absence of which is judged by the court.

The criteria for classifying cases as insignificant, first of all, depend on whether the claims are property in nature, that is, the price of the claim. It is argued that the use by the legislator of the evaluation category of "case of insignificant complexity" as a criterion for referring a case to insignificant negatively affects the legal certainty of this issue. The existence of a link between the recognition of a case of insignificant nature and the order of its consideration (in summary proceedings) gives grounds to argue that cases of insignificant complexity should be recognized, in particular, cases that do not require a preparatory hearing. It is a matter of a fair, impartial and timely hearing, and the decisions of which can be secured without committing procedural actions by the court in preparatory proceedings.

Also, the legal problem that a court must resolve when considering a case should not be too complicated. As a rule, this applies to cases in which a settled case law of their consideration has already been formed, in particular, existing legal opinions of the Supreme Court in similar cases regarding the application of the rules of law to be applied.

Proposals for improvement of the legal regulation of the simplified lawsuit are formulated in order to eliminate the contradictions of the rules of procedural law.

Key words: justice, civil process, minor cases, principles of law, claim proceedings, small-scale case, legal certainty. 